\title{
Transatlantica
}

Revue d'études américaines. American Studies Journal

1 | 2017

Morphing Bodies: Strategies of Embodiment in

Contemporary US Cultural Practices

\section{Merve Emre, Paraliterary: the Making of Bad Readers in Postwar America}

\section{Elsa Court}

\section{(2) OpenEdition}

\section{Journals}

Electronic version

URL: https://journals.openedition.org/transatlantica/9167

DOI: 10.4000/transatlantica.9167

ISSN: 1765-2766

\section{Publisher}

Association française d'Etudes Américaines (AFEA)

Electronic reference

Elsa Court, "Merve Emre, Paraliterary: the Making of Bad Readers in Postwar America", Transatlantica [Online], 1 | 2017, Online since 16 October 2018, connection on 20 May 2021. URL: http://

journals.openedition.org/transatlantica/9167 ; DOI: https://doi.org/10.4000/transatlantica.9167

This text was automatically generated on 20 May 2021.

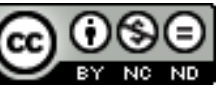

Transatlantica - Revue d'études américaines est mise à disposition selon les termes de la licence Creative Commons Attribution - Pas d'Utilisation Commerciale - Pas de Modification 4.0 International. 


\title{
Merve Emre, Paraliterary: the Making of Bad Readers in Postwar America
}

\author{
Elsa Court
}

\section{REFERENCES}

Merve Emre, Paraliterary: the Making of Bad Readers in Postwar America, Chicago:

University of Chicago Press, 2017, Paperback 27.50 \$, ISBN: 9780226473970, 304 pages.

1 The valorisation of reading practices across disciplines and social groups is dependent on historical contexts, communities, and human agents acting within them. Such is the very plausible argument which Merve Emre's book, Paraliterary: the Making of Bad Readers in Postwar America, aims to put forward in the face of a lack of academic attention to reading practices in the field of 20th century literature. Few modern writers, perhaps, were so hermetic to the idea that their own intellectual principles could have been contingent on historic and institutional values as Russian-American novelist Vladimir Nabokov. It makes sense therefore that the introduction to Emre's book should open with a paraliterary text - a text about the reading of literature illustrating Nabokov's professed values on the correct approach to his taught subject. This document, the "Pop Quiz" Nabokov designed for the introductory lecture to his European Literature course at Cornell University, has been, Emre tells us, widely circulated in English classrooms across higher education since the late 1940s.

Presented as a multiple-answer mock test, the quiz was given to Nabokov's literature students as a way of distinguishing between "good" and "bad" readers among them. Holding that the "good" reader should have imagination, memory, some artistic sense, and be in the possession of a dictionary, the quiz remaining "wrong" answers include identification with the main characters, awareness of the book's screen adaptation, and attention to the socio-economic angle presented by the work of fiction. Under these provisions, those of Nabokov's students who selected the incorrect answers were immediately identified as "bad" readers - and, implicitly, encouraged to revise their 
attitudes to reading. The assumption was that, in a postwar context where book clubs and Hollywood adaptations were significantly changing reading practices in America, this latter category of readers would have been a majority in a large number of classrooms.

The concept of "bad" reading is subsequently theorised in Paraliterary as a judgement of value assumed by the institutions of higher education specialising in the study of literary texts. The book assumes that, from the early 20th century, such institutions in the United States had held dear the importance of establishing a literary canon for America, which required the conceptualisation of literature's value as intrinsic and non-transferable to other areas of life. From this premise, Emre's book aims to historicise the shift, in postwar America, of the reading of literature from these elite academic institutions to institutions that actively emphasised and promoted, much against the university's gospel, literature's "communicative and public value" in the context of a "rapidly internationalising world" (3). Emre's book therefore works at the intersection of two histories, neither of which is literary: a history of the intellectual strands of postwar America's approaches to foreign policy, and a history of how nonacademic infrastructures co-opted the reading of literature for purposes other than the appreciation of literature itself.

- Emre's book strikes one as accounting for both its original strength and some of its limitations. Right from the first and second chapters, Emre extends her category of paraliterary texts from written to oral communication and, in fact, to non-verbal acts of self-presentation and social positioning, bringing attention to Henry James' promotion of European manners in his 1905 American lecture tour at a series of women's colleges on the one hand, and the birth of American Studies as a by-product of the Fulbright fellowship programme on the other. Reading the journals and letters of Fulbright scholar Sylvia Plath in the 1950s, she makes a case for observing the strong affective strategy deployed by organisers of the programme in their effort to win a place of choice for American literature among Europe's English departments. Noting the care with which Plath presented herself to Cambridge society in the year of her fellowship, from her notes on social composure to her modelling of spring fashion items in the university magazine, Emre notes how, besides literary and intellectual credentials, self-presentation "was crucial to the mid-century public sphere" (59), especially in an international context where American culture was set to win the hearts and minds of Europe's educated elite.

Chapter three discusses "Brand Reading" through the American Express as an institution promoting not only free movement for Americans but also the cultivation of national identity through the branding of vacationing subjects and their behavior patterns. Chapter Four, "Sight Reading," discusses National Geographic's aesthetics and cultural value, while Chapter Five, "Reading Like a Bureaucrat," engages with the People-to-People Initiative (PTPI) under Eisenhower and the paraliterary genre of its bureaucracy. Chapter Six, "Reading Like a Revolutionary," explores the "KING ALFRED" conspiracy from the 1967 novel The Man Who Cried I Am, a conspiracy whose author, African American novelist John A. Williams, proceeded to circulate separately through pamphlets in a revolutionary act of paranoid reading as resistance.

6 This is not to say that literary departments in the United States - and the critics they produced - didn't go on promoting "good" reading along similar lines as Nabokov's. Never before the post-World War II period, Emre argues, had college-educated readers 
in America been so anxious to align their reading practices with the stated intents of the country's "good" writers. The desire to appreciate literary texts as serious works of art may be identified as characteristic of the way reading American fiction has been branded and promoted since the postwar period, and which defined itself in an oppositional position to the "curiously undifferentiated" (2) mass of readers who were reading literature for purposes other than artistic, the kind of readers Nabokov and others would have identified as "bad". In this context, an overview of "bad" reading practices supported by case studies of their distinct purposes may seem crucial in telling us what postwar American literature understood itself to be in the first instance:

If, as one critic insists, "the core of a thing called literature" is simply "what people in literature departments do," then it would be impossible to grasp the pressurized formation of the structural integrity of this core without understanding what people outside of literature departments did (and continue to do) with literary texts. (5)

7 The simplicity with which Emre refers throughout the book to this broad category of readers as indiscriminately "bad" could be misleading at first, but is actually testimony to the author's undoubtedly taking issue with the judgement of value implicit in the conceptualisation of reading practices in the margins of elite institutions of learning. Each of her case studies works towards the conclusion that reading literature is an activity which may impact on social and personal human relations as well as international communications and diplomacy in ways which exceed the university's traditional tools to read and understand texts.

8 While the monthly magazine College Teacher commanded, in 1973, "bad" readers to restrict themselves to "menu reading, cook books, 'how to' manuals, comic books, advertisement, magazines, newspapers, and simple novels" (5), authors of serious novels certainly did not limit themselves to literature, as Nabokov's Lolita, with its broad range of paraliterary texts, testifies. The lifeblood of many an American novel of the period is in its borrowing from the world book clubs, movie magazines, hotel notices, tour guides, study-abroad programmes, and the omnipresent romance of brands.

If, as Emre argues quite convincingly throughout, the apparatus of American promotion on the postwar international scene involved a complex network system of texts and textual practices around the production and consumption of literature, it may be difficult at times to distinguish between the institutions that are paraliterary because of their using of literature for political or social purposes, and the institutions that made it into this category because they are represented in works of literature and/ or facilitating writing in some other way. This is the case, for example, in the third chapter on the American Express, in which the author attempts to demonstrate the relationship between American tourism as embodied by a flourishing social and commercial institution and the Cold War counterculture which drew on the homogenisation of the American tourist in order to fashion their own presence as a force of opposition on the postwar cultural scene. While the American Express card or the traveler's cheque facilitated the free wanderings - and writings - of counterculture figures such as Burroughs and Erica Jong, the institutional experience of national identity delivered worldwide by the American Express' office space is portrayed as an embodiment of the mainstream culture Gregory Corso and the Beats react against. Ultimately, recognising the ambivalence of the positioning of literary production in this economic context is one of the book's valuable achievements, even if 
it is built on a somewhat liquid conceptualisation of what Emre freely calls "modern institutions of literacy" (95).

10 In the end, Emre's original concept of the paraliterary as an alternative category of reading models to those thoughts at the institutional space of the literature department guides the reader through a compelling and often challenging set of arguments. The book feels particularly timely in a moment when the humanities worldwide are being asked, increasingly, to prove their "usefulness" to the university and its consumers in the face of funding cuts, subject diversification, and general economic uncertainty for graduates' futures.

INDEX

Subjects: Recensions

\section{AUTHORS}

\section{ELSA COURT}

Independent Researcher 